\title{
Ascending cholangitis presenting with Lactococcus lactis cremoris bacteraemia: a case report
}

\author{
Jane Davies* ${ }^{* 1}$, Michael David Burkitt ${ }^{\dagger 2}$ and Alastair Watson ${ }^{2}$
}

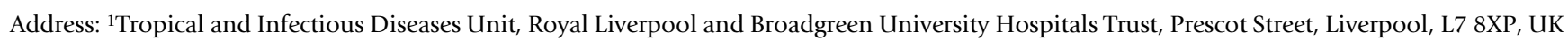
and ${ }^{2}$ The Henry Wellcome Laboratories, Unit of Gastroenterology, School of Clinical Science, 1st Floor Nuffield Building, Ashton Street, The University of Liverpool, Liverpool, L69 3GE, UK

Email: Jane Davies* - janedavies4@nhs.net; Michael David Burkitt - m.d.burkitt@liverpool.ac.uk;

Alastair Watson - alastair.watson@liverpool.ac.uk

* Corresponding author †Equal contributors

Published: 6 January 2009

Journal of Medical Case Reports 2009, 3:3 doi:10.1 186/1752-1947-3-3

This article is available from: http://www.jmedicalcasereports.com/content/3/I/3

(C) 2009 Davies et al; licensee BioMed Central Ltd.

This is an Open Access article distributed under the terms of the Creative Commons Attribution License (http://creativecommons.org/licenses/by/2.0), which permits unrestricted use, distribution, and reproduction in any medium, provided the original work is properly cited.
Received: 18 February 2008

Accepted: 6 January 2009

\begin{abstract}
Introduction: A case of Lactococcus lactis cremoris causing cholangitis is described. This Grampositive organism is not routinely considered to be pathogenic in immunocompetent individuals. To our knowledge, this is the thirteenth report of invasive infection and the first of cholangitis to be reported in association with this organism.
\end{abstract}

Case presentation: A 72-year-old patient presented with Charcot's triad and was demonstrated to have cholangitis with Lactococcus lactis cremoris bacteraemia. Biliary drainage was achieved through endoscopic retrograde cholangiography. Antibiotic therapy with multiple agents was necessary.

Conclusion: This report provides corroboration of evidence that Lactococcus lactis cremoris is a potential pathogen in immunocompetent adults. There remains a debate about the most appropriate empirical antibiotic therapy in this condition. In the light of this case, it is important to keep an open mind to potential pathogens.

\section{Introduction}

Lactococcus lactis cremoris is commonly considered to be a non-pathogenic organism in humans. It is recognized as a commensal organism of mucocutaneous surfaces, however, over the past 50 years, there have been a number of case reports [1-11] demonstrating the potential for this organism to cause infection. We report the first case of cholangitis associated with septicaemia caused by Lactococcus lactis cremoris.

\section{Case presentation}

A 72-year-old lady, normally fit and well, presented with a 5-day history of jaundice and abdominal pain. She was nauseated and had dark urine. On initial assessment, she was deeply icteric and her temperature was $38.2^{\circ} \mathrm{C}$ but she was haemodynamically stable. Systemic examination did not reveal any other abnormalities, specifically there were no stigmata of chronic liver disease. No organs or lymph nodes were palpable and the abdomen was soft and non-tender.

Biochemical analyses demonstrated a leukocytosis and neutrophilia; haemoglobin $(\mathrm{Hb}) 11.9 \mathrm{~g} / \mathrm{dL}$, white blood cell count (WCC) $13.9 \times 10^{9} / \mathrm{L}$, neutrophils $11.4 \times 10^{9} / \mathrm{L}$. An acute phase response was evident with C-reactive protein (CRP) $131 \mathrm{mg} / \mathrm{L}$. A mixed cholestatic and hepatic pic- 
ture of hepatic enzymes with alkaline phosphatase (ALP) $340 \mathrm{U} / \mathrm{L}$, alanine aminotransferase (ALT) $240 \mathrm{U} / \mathrm{L}$ and gamma-glutamyl-transferase ( $\gamma \mathrm{GT}$ ) $381 \mathrm{U} / \mathrm{L}$ was demonstrated; total bilirubin was $351 \mu \mathrm{mol} / \mathrm{L}$. Hepatic synthetic function was preserved with albumin $30 \mathrm{~g} / \mathrm{L}$ and prothrombin time (PT) of 13.8 seconds. A clinical diagnosis of cholangitis was made on the basis of Charcot's triad (abdominal pain, fever and jaundice), and empirical antibiotic therapy (oral ciprofloxacin $500 \mathrm{mg}$ bd) was commenced.

An ultrasound of the biliary tree was performed demonstrating dilatation of the common bile duct to $1.5 \mathrm{~cm}$ with visualization of at least one stone in the lumen of the duct. Intrahepatic duct dilatation was also noted. Blood cultures confirmed a Lactococcus lactis cremoris septicaemia. The organism was sensitive to tazobactam/piperacillin and co-amoxiclav. In light of these results, antibiotic therapy was changed to intravenous tazobactam/piperacillin $4.5 \mathrm{~g}$ tds.

The patient proceeded to endoscopic retrograde cholangiopancreatogram (ERCP) where an impacted common bile duct stone was identified. Unfortunately, this was not amenable to endoscopic removal despite sphincterotomy; however two biliary stents were inserted with good drainage.

The patient recovered rapidly with resolution of her symptoms and signs and was discharged home 48 hours postERCP. Treatment was completed with 2 weeks of oral coamoxiclav $625 \mathrm{mg}$ tds.

\section{Discussion}

The Tokyo Consensus guidelines of 2007 have now established definitive diagnostic criteria and severity assessment of cholangitis [12]. The diagnosis of cholangitis is made either by the presence of Charcot's triad or by the presence of two of these features backed up by abnormal liver function tests, raised inflammatory markers and imaging demonstrating a dilated biliary tree. Severity is assessed by the presence or absence of organ failure once a diagnosis has been made and response to initial therapy. As our patient had no signs of organ failure but failed to respond to the primary treatment, she constitutes cholangitis of moderate severity.

Empirical antibiotic therapy for cholangitis is targeted towards gut organisms, particularly Gram-negative organisms. Commonly (including in our unit), ciprofloxacin is considered to be an appropriate empirical therapy. This is backed up by reports of an $85 \%$ clinical cure rate in trials [13]. The Tokyo Consensus group [13] failed to recommend a single specific empirical treatment, therefore local antibiotic guidelines will continue to direct empirical therapy. In the presence of positive microbiological investigations, there is a clear consensus that agents should be changed for more appropriate treatment according to sensitivity.

Biliary drainage reduces mortality and speeds recovery from cholangitis and is therefore a vital part of management [14]. The Tokyo guidelines recognize that this must be done in an emergency setting for patients with severe cholangitis and as promptly as practical in other patients. Endoscopic drainage is the preferred modality [15].

Lactococcus lactis cremoris is a Gram-positive coccus, formerly classified as Streptococcus cremoris but now recognized as a member of the genus Lactococcus [3]. This species is commonly regarded as non-pathogenic in immunocompetent adults, however we report the thirteenth case to our knowledge of this pathogen causing clinically significant infection. Previously, four cases of bacterial endocarditis $[4,6,9,11]$, one of septicaemia [7], two liver abscesses $[3,5]$ and one each of necrotizing pneumonitis [10], septic arthritis [8], deep neck infection [2], cerebellar abscess [4] and canaliculitis [1] have been reported. Of these, it appears that nine were immunocompetent patients. All bar one of the case reports were in adults (Table 1).

Lactococcus lactis cremoris is a recognized skin commensal of cattle and is also used in the dairy industry for milk fermentation. It may therefore be present in unpasteurized dairy products. Of the previously reported cases, six have been associated with a clear history of exposure to unpasteurized dairy products; in one of these cases, the organism was isolated from the milk product (Table 1). Our patient is not aware of having had any such exposure.

\section{Conclusion}

This report provides corroboration of evidence that Lactococcus lactis cremoris is a potential pathogen in immunocompetent adults. Lactococcus lactis cremoris has now been reported as a pathogen in many different systems, both acutely and subacutely. This may well represent an underreporting of the true incidence of invasive infection related to this organism.

Diagnosis and assessment of the clinical severity of cholangitis are now the subject of consensus guidelines. These guidelines also extend to the appropriate timing and method of biliary drainage. However, there remains a debate about the most appropriate empirical antibiotic therapy in this condition. In the light of this case, it is important to consider other potential pathogens causing ascending cholangitis. 
Table I: Previously reported cases of Lactococcus lactis cremoris associated infections

\begin{tabular}{|c|c|c|c|c|c|c|c|}
\hline Year & Age & Sex & Site of infection & $\begin{array}{l}\text { Exposure to } \\
\text { unpasteurized milk } \\
\text { products }\end{array}$ & Treatment & Outcome & Immune status \\
\hline $2006[1]$ & 80 & $\mathrm{~F}$ & Canaliculitis & None & $\begin{array}{l}\text { Oral ampicillin and } \\
\text { topical chloramphenicol }\end{array}$ & Complete resolution & Normal \\
\hline 2005 [2] & 68 & M & Deep neck infection & $\begin{array}{l}\text { Cow breeder and } \\
\text { consumed } \\
\text { unpasteurized milk }\end{array}$ & $\begin{array}{l}\text { Ceftriaxone and } \\
\text { metronidazole for } 6 \\
\text { weeks }\end{array}$ & Resolution on discharge & $\begin{array}{l}\text { Previous } \\
\text { malignancy }\end{array}$ \\
\hline 2004 [3] & 79 & $\mathrm{~F}$ & Liver abscess & None & $\begin{array}{l}\text { Percutaneous drainage, } \\
\text { Imipenem Cilastatin for } \\
5 \text { weeks }\end{array}$ & Complete resolution & Normal \\
\hline $2002[4]$ & 45 & $\mathrm{~F}$ & Cerebellar abscess & Not commented & $\begin{array}{l}\text { Ceftriaxone } 8 \text { weeks, } \\
\text { gentamicin } 2 \text { weeks, } \\
\text { Metronidazole }\end{array}$ & $\begin{array}{l}\text { No residual deficit and no } \\
\text { recurrence at } 9 \text { months }\end{array}$ & Normal \\
\hline \multirow[t]{2}{*}{2002 [3] } & 67 & $M$ & Endocarditis & $\begin{array}{l}\text { History of drinking } \\
\text { unpasteurized milk }\end{array}$ & $\begin{array}{l}\text { Co-amoxiclav and } \\
\text { gentamicin } 15 \text { days }\end{array}$ & $\begin{array}{l}\text { Well } 6 \text { months post } \\
\text { discharge }\end{array}$ & Normal \\
\hline & & & & & Penicillin for 6 weeks & & \\
\hline \multirow[t]{4}{*}{$2000[5]$} & 14 & $\mathrm{~F}$ & Liver abscess & None & Percutaneous drainage & $\begin{array}{l}\text { Discharged from hospital } \\
\text { on day } 48\end{array}$ & Normal \\
\hline & & & & & $\begin{array}{l}\text { Cefotiam, Amikacin and } \\
\text { Clindamycin for } 8 \text { days }\end{array}$ & & \\
\hline & & & & & Panipenem for 8 days & & \\
\hline & & & & & $\begin{array}{l}\text { Piperacillin } 15 \text { days and } \\
\text { amikacin } 10 \text { days }\end{array}$ & & \\
\hline 1996 [6] & 56 & $M$ & Endocarditis & None & $\begin{array}{l}\text { Penicillin } G \text { for } 12 \text { days } \\
\text { and Clarithromycin for } \\
18 \text { days }\end{array}$ & $\begin{array}{l}\text { Well } 18 \text { months post } \\
\text { discharge }\end{array}$ & Normal \\
\hline 1995 [7] & 69 & M & Septicaemia & Yoghurt ingested & $\begin{array}{l}\text { Cefotaxime and } \\
\text { Amikacin }\end{array}$ & No comment & $\begin{array}{l}\text { Chronic } \\
\text { lymphocytic } \\
\text { leukaemia }\end{array}$ \\
\hline 1993 [8] & 57 & $\mathrm{~F}$ & Septic arthritis & Unpasteurized milk & Penicillin for 6 weeks & $\begin{array}{l}\text { Deformity } 8 \text { months post } \\
\text { discharge, but no ongoing } \\
\text { infection }\end{array}$ & Normal \\
\hline 1990 [9] & 65 & $\mathrm{~F}$ & Endocarditis & Not commented & $\begin{array}{l}\text { Benzylpenicillin and } \\
\text { gentamicin }\end{array}$ & No ongoing infection & Normal \\
\hline $1990[10]$ & 24 & $M$ & $\begin{array}{l}\text { Necrotizing } \\
\text { pneumonitis and } \\
\text { empyema }\end{array}$ & $\begin{array}{l}\text { Unpasteurized milk } \\
\text { and cheese eaten }\end{array}$ & $\begin{array}{l}\text { Thoracocentesis }(* 3) \\
\text { Penicillin and } \\
\text { clindamycin } 15 \text { days }\end{array}$ & $\begin{array}{l}\text { Well I month post } \\
\text { discharge }\end{array}$ & HIV positive \\
\hline $1955[11]$ & 21 & $M$ & Endocarditis & $\begin{array}{l}\text { Sour cream known to } \\
\text { contain S. Lactis }\end{array}$ & $\begin{array}{l}\text { Penicillin and } \\
\text { Dihydrostreptomycin } \\
\text { for } 22 \text { days }\end{array}$ & $\begin{array}{l}\text { Well } 4 \text { months post } \\
\text { discharge }\end{array}$ & Normal \\
\hline
\end{tabular}

\section{Abbreviations}

Hb: haemoglobin; WCC: white cell count; CRP: C-reactive protein; ALT: alanine aminotransferase; ALP: alkaline phosphatase; $\gamma \mathrm{GT}$ : gamma-glutamyl-transferase; PT: prothrombin time; bd: twice daily; tds: three times daily; ERCP: endoscopic retrograde cholangiopancreatogram

\section{Consent}

Written informed consent was obtained from the patient for publication of this case report and any accompanying images. A copy of the written consent is available for review by the Editor-in-Chief of this journal.

\section{Competing interests}

The authors declare that they have no competing interests.

\section{Authors' contributions}

JD and MDB were involved in patient care, carried out the review of literature and were jointly responsible for drafting and revising the manuscript. AJMW has provided editorial and clinical supervision.

\section{References}

I. Leung DYL, Kwong YYY, Ma CH, Wong WM, Lam DSC: Canaliculitis associated with a combined infection of lactococcus lactis cremoris and eikenella corrodens. Jpn J Ophthalmol 2006, 50:284-298.

2. Koyuncu M, Acuner IC, Uyar M: Deep neck infection due to lactococcus lactis cremoris: A case report. Eur Arch Otorhinolaryngol 2005, 262(9):7|9-72|.

3. Antolin J, Ciguenza R, Saluena E, Vazquez J, Hernandez J, Espinos D: Liver abscess caused by lactococcus lactis cremoris: A new pathogen. Scand J Infect Dis 2004, 36:490-49I.

4. Akhaddar A, El Mostarchid B, Gazzaz M, Boucetta M: Cerebellar abscess due to lactococcus lactis. A new pathogen. Acta Neurochir (Wien) 2002, I 44:305-306. 
5. Nakarai T, Morita K, Nojiri Y, Nei J, Kawamori Y: Liver abscess due to lactococcus lactis cremoris. Paediatr Int 2000, 42:699-70I.

6. Pellizzer G, Benedetti P, Biavasco F, Manfrin V, Franzetti M, Scagnelli M, Scarparo C, de Lalla F: Bacterial endocarditis due to lactococcus lactis subsp. cremoris: case report. Clin Microbiol Infect 1996, 2:230-232.

7. Durand JM, Rousseau MC, Gandois JM, Kaplanski G, Mallet MN, Soubeyrand J: Streptococcus lactis septacemia in a patient with chronic lymphocytic leukemia. Am J Hematol 1995, 50:64-65.

8. Campbell P, Dealler S, Lawton JO: Septic arthritis and unpasteurised milk. J Clin Pathol 1993, 46: 1057-I 058.

9. Mannion PT, Rothburn MM: Diagnosis of bacterial endocarditis caused by Streptococcus lactis and assisted by immunoblotting of serum antibodies. J Infect 1990, 21:317-326.

10. Torre D, Sampietro C, Fiori GP, Luzzaro F: Necrotizing pneumonitis and emphysema caused by streptococcus cremoris from milk. Scand J Infect Dis 1990, 22:221-222.

II. Wood HF, Jacobs K, McCarty M: Streptococcus lactis isolated from a patient with subacute bacterial endocarditis. Am J Med 1955, Feb:345-347.

12. Wada K, Takada T, Kawarada Y, Nimura Y, Miura F, Yoshida M, Mayumi T, Strasberg S, Pitt HA, Gadacz TR, Büchler MW, Belghiti J, de Santibanes E, Gouma DJ, Neuhaus H, Dervenis C, Fan ST, Chen MF, Ker CG, Bornman PC, Hilvano SC, Kim SW, Liau KH, Kim MH: Diagnostic criteria and severity assessment of acute cholangitis: Tokyo Guidelines. J Hepatobiliary Pancreat Surg 2007, 14:52-58.

13. Tanaka A, Takada T, Kawarada Y, Nimura Y, Yoshida M, Miura F, Hirota M, Wada K, Mayumi T, Gomi H, Solomkin JS, Strasberg SM, Pitt HA, Belghiti J, de Santibanes E, Padbury R, Chen MF, Belli G, Ker CG, Hilvano SC, Fan ST, Liau KH: Antimicrobial therapy for acute cholangitis: Tokyo Guidelines. J Hepatobiliary Pancreat Surg 2007, 14:59-67.

14. Lygidakis NJ: Acute suppurative cholangitis: Comparison of internal and external biliary drainage. Am J Surg 1982, 1 43:304-306.

15. Nagino M, Takada T, Kawarada Y, Nimura Y, Yamashita Y, Tsuyuguchi T, Wada K, Mayumi T, Yoshida M, Miura F, Strasberg SM, Pitt HA, Belghiti J, Fan ST, Liau KH, Belli G, Chen XP, Lai EC, Philippi BP, Singh $H$, Supe $A$ : Methods and timing of biliary drainage for acute cholangitis: Tokyo Guidelines. J Hepatobiliary Pancreat Surg 2007, 14:68-77.
Publish with Bio Med Central and every scientist can read your work free of charge

"BioMed Central will be the most significant development for disseminating the results of biomedical research in our lifetime. "

Sir Paul Nurse, Cancer Research UK

Your research papers will be:

- available free of charge to the entire biomedical community

- peer reviewed and published immediately upon acceptance

- cited in PubMed and archived on PubMed Central

- yours - you keep the copyright
BioMedcentral 